DOI https://doi.org/10.30525/978-9934-26-149-7-4

\title{
Nataliia VOLKOVA
}

Doctor of Pedagogical Sciences, Professor, Head of the Department of Innovative Technologies on Pedagogics, Psychology and Social Work, Alfred Nobel University, 18 Sicheslavska Naberezhna Str., Dnipro, Ukraine, 49000

E-mail: npvolkova@yahoo.com

ORCID: 0000-0003-1258-7251

Scopus-Author ID: 57204968168

\section{Наталія ВОЛКОВА}

доктор педагогічних наук, професор, завідувач кафедри інновачійних технологій з педагогіки, психології та сочіальної роботи, ВНЗ «Університет імені Альфреда Нобеля», вул. Січеславська Набережна, 18, м. Дніпро, Україна, 49000

\section{Olha LEBID}

Doctor of Pedagogical Sciences, Docent, Deputy Head of the Department of Innovative Technologies on Pedagogics, Psychology and Social Work, Alfred Nobel University, 18 Sicheslavska Naberezhna Str., Dnipro, Ukraine, 49000

E-mail: swan_ov@ukr.net

ORCID: 0000-0001-6861-105X

ResearcherID: AAG-3865-2020

Scopus-Author ID: 57214945815

Ольга ЛЕБІДЬ

доктор педагогічних наук, дочент, заступник завідувача кафедри інновачійних технологій з педагогіки, психологї та сочіальної роботи, ВНЗ «Університет імені Альфреда Нобеля», вул. Січеславська Набережна, 18, м. Дніпро, Україна, 49000

\section{CONTENT, FORMS, AND METHODS OF TRAINING PHD STUDENTS FOR WRITING AND IMPLEMENTATION OF A THESIS PAPER}

Abstract. The problem of preparation of doctors of philosophy for writing and realization of the dissertation project is considered in the article. Based on the results of the analysis of the conceptual and categorical apparatus on the researched problem, approaches to definition of essence of preparation for project activity, taking into 
account features of object of research the concept "preparation for writing and realization of the dissertation project» is specified. The course and results of a pilot study aimed at clarifying the perceptions of respondents about the peculiarities of the preparation of future doctors of philosophy to write and implement a dissertation project in graduate school; identification of methods and forms that contribute to the effective preparation of graduate students for writing and implementing a dissertation project. Peculiarities of preparation for writing and realization of the dissertation project of future doctors of philosophy, who study according to the educational-scientific program "Professional education", specialty 015 Professional education (by specializations) are revealed. Emphasis is placed on the peculiarities of modeling the content of the educational and scientific program: the inclusion of those disciplines, the content of which would help applicants in writing and implementing a dissertation project; before the presentation of each discipline, acquaintance with the topics of dissertation research of graduate students of this group and modeling the content of each lesson, focusing as much as possible on those issues that are important for writing a dissertation project; study of certain issues of the discipline, based on the content of defended dissertations in one-time specialized councils of the Alfred Nobel University; introduction of training courses "Project Management in Education" and "Fundraising in Education"; organization of research activities of graduate students by means of information technology, self-training in the library and with the help of the Internet, information support of applicants; use of elements of postgraduate research in educational activities; participation of future doctors of philosophy in events on educational, scientific, research activities conducted both in Ukraine and abroad, etc.

Key words: project, dissertation project, doctor of philosophy, preparation for writing and realization of dissertation project, postgraduate study, educational-scientific program "Professional education". 


\section{ЗМІСТ, ФОРМИ І МЕТОДИ ПІДГОТОВКИ ДОКТОРІВ ФІЛОСОФІЇ ДО НАПИСАННЯ І РЕАЛІЗАЦІЇ ДИСЕРТАЦЙННОГО ПРОЄКТУ}

Анотація. У статті розглянуто проблему підготовки докторів філософії до написання $і$ реалізачії дисертаційного проєкту. На основі результатів аналізу понятійно-категоріального апарату 3 досліджуваної проблеми, підходів до визначення сутності підготовки до проєктної діяльності, з урахуванням особливостей об'єкта дослідження уточнено поняття «підготовка до написання $i$ реалізації дисертацийного проєкту». Представлено хід та результати пілотного дослідження, спрямованого на з'ясування уявлень респондентів щоодо особливостей підготовки майбутніх докторів філософії до написання $i$ реалізації дисертаційного проєкту в умовах аспірантури; визначення методів $i$ форм, щзо сприяють ефективній підготовиі аспірантів до написання $i$ реалізаиії дисертаиійного проєкту. Розкрито особливості підготовки до написання та реалізаиії дисертаційного проєкту майбутніх докторів філософіі, які навчаються за освітньонауковою програмою «Професійна освіта», спеціальність 015 Професійна освіта (за спеціалізаціями). Акиентовано увагу на особливостях моделювання змісту освітньо-наукової програми: включення тих навчальних дисииплін, зміст яких допомагав би здобувачам у написанні та реалізації дисертаційного проєкту; перед викладом кожної навчальної дисципліни ознайомлення із темами дисертаційних досліджень аспірантів даної групи і моделювання змісту кожного заняття, максимально акиентуючи увагу на тих питаннях, які є вагомими для написання дисертаційного проєкту; вивчення окремих питань дисципліни, базуючись на змісті захищених дисертащій в разових спеціалізованих радах ВНЗ «Університет імені Альфреда Нобеля»; впровадження навчальних курсів «Управління проєктами в сфері освіти» і «Фандрайзинг в освітній діяльності»; організація пошукової дослідницької діяльності аспірантів засобами інформаційних технологій, самопідготовки в бібліотеці та за допомогою Інтернет, інформаційної підтримки здобувачів; використання елементів досліджень аспірантів в освітній діяльності; участь майбутніх докторів філософії у заходах $з$ освітньої, наукової, науково-дослідної діяльності, щуо проводяться як в Україні так $і$ за ї̈ межами тощо. 
Ключові слова: проєкт, дисертаційний проєкт, доктор філософії, підготовка до написання та реалізації дисертаційного проєкту, аспірантура, освітньо-наукова програма «Професійна освіта».

Вступ. Інтеграція України в європейський та всесвітній освітній і науковий простір, світоглядні, економічні, соціально-політичні виклики VUCA-світу (V (Volatility) - нестабільність, мінливість, $\mathrm{U}$ (Uncertainty) - невизначеність, непередбачуваність, $\mathrm{C}$ (Complexity) - складність, багатомірність, А (Ambiguity) неоднозначність), експоненціальне зростання інформаційноцифрового середовища актуалізують питання щодо якості педагогічної освіти, а отже, вдосконалення підготовки педагогічних кадрів вищої кваліфікації для професійної та вищої освіти. Це соціальне замовлення для системи професійної педагогічної освіти має чітко окреслену законодавчу базу.

Відповідно до Закону України «Про вищу освіту» ${ }^{1}$, Національної рамки кваліфікації 2 , Концепції розвитку педагогічної освіти ${ }^{3}$, Порядку підготовки здобувачів вищої освіти ступеня доктора філософії та доктора наук у вищих навчальних закладах (наукових установах $)^{4}$, Професійного стандарту на групу професій «Викладачі закладів вищої освіти» ${ }^{5}$ особливої уваги потребують цільові орієнтири професійної підготовки здобувачів третього (освітньо-

1 Закон України «Про вищу освіту» URL: https://zakon.rada.gov.ua/laws/ show/1556-18 (дата звернення: 01.09.2021).

2 Постанова Кабінету Міністрів України «Про затвердження національної рамки кваліфікацій» (в редакції постанови Кабінету Міністрів України від 25 червня 2020 p. № 519). URL: https://zakon.rada.gov.ua/laws/show/519-2020п\#n10 (дата звернення: 02.09.2021)

3 Концепція розвитку педагогічної освіти (затверджена Наказом МOH України від 16 липня 2018 р., № 776). URL: https://mon.gov.ua/ua/npa/prozatverdzhennya-koncepciyi-rozvitku-pedagogichnoyi-osviti (дата звернення: 02.09.2021)

${ }^{4}$ Порядок підготовки здобувачів вищої освіти ступеня доктора філософії та доктора наук у вищих навчальних закладах (наукових установах) від 23 березня 2016 p. № 261. URL: https://zakon.rada.gov.ua/laws/show/261-2016-\%D0\%BF\#Text (дата звернення: 02.09.2021)

5 Професійний стандарт на групу професій «Викладачі закладів вищої освіти» (затверджено наказом Міністерства розвитку економіки, торгівлі та сільського господарства України 23.03.2021, № 610). URL: https://mon.gov.ua/storage/app/media/pto/standarty/2021/03/25/Standart\%20na\%20h rupu\%20profesiy_Vykladachi\%20zakladiv\%20vyshchoyi\%20osvity_25.03.pdf (дата звернення: 10.09.2021) 
наукового) рівня вищої освіти - майбутніх педагогів-дослідників (педагогів-виконавців у мистецькій освіті) для усіх рівнів вищої освіти. Вони мають бути «спроможними нести відповідальність за вироблення та ухвалення рішень у непередбачуваних робочих та/або навчальних контекстах», «управляти робочими або навчальними процесами, які $\epsilon$ складними, непередбачуваними та потребують нових стратегічних підходів» ${ }^{6}$, здатними здійснювати аналітичне осмислення стану та перспектив розвитку сфери освіти (відповідної спеціальності), створювати та впроваджувати новий зміст освіти та новітні методики (технології) навчання, поєднувати власну педагогічну (науково-педагогічну, мистецько-виконавську) діяльність на високому професійному рівні 3 поширенням нових знань і кращої практики в педагогічній спільноті ${ }^{7}$, виконувати дослідницькі/творчі проєкти ${ }^{8}$.

Реалізація зазначеної національної наукової політики можлива в умовах аспірантури, які починаючи з 2016 р. здійснюють підготовку майбутніх докторів філософії - це освітній і водночас перший науковий ступінь, що здобувається на третьому рівні вищої освіти на основі ступеня магістра. Однією з головних умов присудження цього ступеня $\epsilon$ успішне виконання здобувачем вищої освіти відповідної освітньо-наукової програми. Заклади вищої освіти та наукові установи можуть здійснювати підготовку докторів філософії за власною освітньо-науковою програмою згідно 3 отриманою ліцензією на відповідну освітню діяльність 9 .

Відтак проблема розроблення якісних освітньо-наукових програм, пошуку нових інноваційних підходів до формування творчого та

6 Постанова Кабінету Міністрів України «Про затвердження національної рамки кваліфікацій» (в редакції постанови Кабінету Міністрів України від 25 червня 2020 р. № 519). URL: https://zakon.rada.gov.ua/laws/show/519-2020п\#n10 (дата звернення: 02.09.2021)

7 Концепція розвитку педагогічної освіти (затверджена Наказом МOH України від 16 липня 2018 р., № 776). URL: https://mon.gov.ua/ua/npa/prozatverdzhennya-koncepciyi-rozvitku-pedagogichnoyi-osviti (дата звернення: 02.09.2021)

8 Професійний стандарт на групу професій «Викладачі закладів вищої освіти» (затверджено наказом Міністерства розвитку економіки, торгівлі та сільського господарства України 23.03.2021, № 610). URL: https://mon.gov.ua/storage/app/media/pto/standarty/2021/03/25/Standart\%20na\%20h rupu\%20profesiy_Vykladachi\%20zakladiv\%20vyshchoyi\%20osvity_25.03.pdf (дата звернення: 10.09.2021)

9 Закон України «Про вищу освіту» URL: https://zakon.rada.gov.ua/laws/show/ 1556-18 (дата звернення: 01.09.2021). 
наукового потенціалу здобувачів третього рівня вищої освіти, їх здатності розв'язувати комплексні проблеми в галузі професійної та/або дослідницько-інноваційної діяльності, набуває актуальності.

\section{Аналіз останніх досліджень та публікацій. Проблема} підготовки здобувачів третього (PhD) рівня вищої освіти в умовах аспірантури стала предметом уваги вітчизняних (О. Антонова ${ }^{10}$, Л. Бутенко ${ }^{11}, \quad$ А. Вітченко ${ }^{12}, \quad$ I. Козубцов ${ }^{13}, \quad$ І. Линьова ${ }^{14}$, В. Меняйло ${ }^{15}$, Ю. Носенко ${ }^{16}$,

I. Олійник ${ }^{17}$,

О. Пшенична ${ }^{18}$,

10 Антонова О.Є. Системний підхід до підготовки докторів філософії за спеціальністю 011 «Науки про освіту». Інноваційний розвиток вищої освіти: глобальний, європейський та національний виміри змін : матер. V Міжнар. наук.практ. конф. (16-17 квітня 2019 р., м. Суми). Суми: Вид-во СумДПУ імені А.С. Макаренка, 2019. Т. 1. С. 97-100.

${ }^{11}$ Бутенко Л.Л. Методологізація загальнопедагогічної підготовки майбутніх учителів та науково-педагогічних працівників в умовах трирівневої системи вищої освіти : автореф. дис. на здобуття наукового ступеня доктора пед. наук за спеціальністю 13.00.04 - теорія і методика професійної освіти; Державний заклад «Луганський національний університет імені Тараса Шевченка». Старобільськ, 2021. 45 с.

12 Вітченко А. Підготовка майбутніх докторів філософії у вищій військовій школі: досвід, проблеми, шляхи вдосконалення. Військова освіта. 2020. № 1 (41). С. 91-102.

${ }^{13}$ Козубцов I. Теорія та практика розвитку методологічної компетентності в аспірантів: аналіз науково-педагогічної літератури. Збірник наукових праць Уманського державного педагогічного університету імені Павла Тичини. 2014. Вип. 3. С. 154-161.

14 Линьова І.О Оцінювання якості підготовки докторів філософії в контексті євроінтеграції. Аналіз провідного вітчизняного та зарубіжного досвіду щодо оцінювання якості вищої освіти в умовах євроінтеграції: аналітичні матеріали (частина I). За ред. В. Лугового, Ж. Таланової. Київ : Ін-т вищої освіти НАПН України, 2018. С. 157-167.

${ }^{15}$ Меняйло В. Методологічні засади підготовки майбутніх докторів філософії до дослідницько-інноваційної діяльності. Збірник наукових праць Уманського держсавного педагогічного університету. 2020. Вип. 2. Ч. 1. С. 106-120.

16 Спірін О.М., Носенко Ю.Г., Яцишин А.В. Сучасні вимоги і зміст підготовки наукових кадрів вищої кваліфікації з інформаційно-комунікаційних технологій в освіті. Інформаційні технології $і$ засоби навчання. 2016. Т. 56. № 6. C. 219-239.

17 Олійник I.B. Використання інтерактивних технологій у процесі формування дослідницької компетенції майбутніх докторів філософії в умовах аспірантури. Вісник Глухівського начіонального педагогічного університету імені Олександра Довженка. 2018. Вип. 36. С. 59-67.

18 Пшенична О.С. Компетентнісна парадигма підготовки здобувачів ступеня доктора філософії в галузі освіти. Педагогіка формування творчої особистості у вищиій $і$ загальноосвітній иколах. 2017. Вип. 56-57 (109-110). С. 343-349. 

I. Регейло ${ }^{19}$,
О. Семеног ${ }^{20}$,
О. Спірін ${ }^{21}$,
П. Щипанський ${ }^{22}$,

А. Яцишин ${ }^{23}$, та ін.) та зарубіжних дослідників (С. Андерсон (S. Anderson) ${ }^{24}$, А. Аустін (A. Austin) $)^{25}$, С. Гордон (S. Gordon) $)^{26}$, П. Денісоло (P. Denicolo) $)^{27}$ А. Демірболат (A. Demirbolat) ${ }^{28}$, Д. Олівер (J. Oliver) ${ }^{29}$ та ін.). Науковці студіюють власні знахідки щодо моделювання змісту, методів підготовки здобувачів третього $(\mathrm{PhD})$ рівня вищої освіти ${ }^{30}$, впровадження компетентнісного підходу

19 Регейло I. Підготовка наукових і науково-педагогічних кадрів вищої кваліфікації в Україні у XX - початку XXI століття : монографія. Київ : Освіта України, 2014. 704 с.

${ }^{20}$ Семеног О. Академічна культура - фундаментальний складник підготовки доктора філософії зі спеціальності 015 «Професійна освіта». Педагогічні науки: теорія, історія, інноващійні технології. 2016. № 5 (59). С. 192-203.

21 Спірін О.М., Носенко Ю.Г., Яцишин А.В. Сучасні вимоги і зміст підготовки наукових кадрів вищої кваліфікації з інформаційно-комунікаційних технологій в освіті. Інформаційні технологї і засоби навчання. 2016. Т. 56. № 6. C. 219-239.

22 Щипанський П.В., Корецький А.А., Капосльоз Г.В., Зайцев Н.Н. Організація підготовки докторів філософії у країнах Європейського союзу та Україні: стан, тенденції, перспективи. Збірник наукових праць Центру воєнностратегічних досліджень. 2018. № 2 (63). С. 136-142.

23 Спірін О.М., Носенко Ю.Г., Яцишин А.В. Сучасні вимоги і зміст підготовки наукових кадрів вищої кваліфікації з інформаційно-комунікаційних технологій в освіті. Інформаційні технології $і$ засоби навчання. 2016. Т. 56. № 6, C. 219-239.

24 Anderson S. \& Anderson B. (2012). Preparation and Socialization of the Educational Professoriate: Narratives of Doctoral Student-Instructors. The Journal of Teaching and Learning in Higher Education, 24 (2), 239-251. URL: http://www.isetl.org/ijtlhe/pdf/IJTLHE1279.pdf (accessed: 9 September 2021).

25 Austin A.E., \& McDaniels M. (2006). Using doctoral education to prepare faculty to work within Boyer's four domains of scholarship. New Directions for Institutional Research, 129, 51-65.

${ }^{26}$ Gordon S.P., Oliver J. (2015). Examining the Value Master's and PhD Students. Place on Various Instructional Methods in Educational Leadership Preparation. International Journal of Educational Leadership Preparation, 10 (21), 77-98.

27 Denicolo, P. (2004). Doctoral supervision of the vebeer of satisfaction and competence. Studies in Higher Education, 29 (6), 693-707.

${ }^{28}$ Demirbolat, A. (2005). Yüksek lisans öğrencilerinin programdan ve öğretim elemanlarından beklentileri. [The expectations of the post graduate students about the program and the academic staff]. Türk Ĕ̈itim Bilimleri Dergisi, 1 (3), 47-64.

${ }^{29}$ Gordon S.P., Oliver J. (2015). Examining the Value Master's and PhD Students. Place on Various Instructional Methods in Educational Leadership Preparation. International Journal of Educational Leadership Preparation, 10 (21), 77-98.

30 Спірін О.М., Носенко Ю.Г., Яцишин А.В. Сучасні вимоги і зміст підготовки наукових кадрів вищої кваліфікації з інформаційно-комунікаційних технологій в освіті. Інформаційні технологї $і$ засоби навчання. 2016. Т. 56. № 6. C. 219-239. 
в підготовці майбутніх докторів філософії 31 , вивчення методологічних засад підготовки майбутніх докторів філософії ${ }^{32}$, розвитку системи забезпечення якості підготовки докторів філософії $^{33}$, формування дослідницької ${ }^{34}$, методологопраксеологічної компетентності ${ }^{35}$, акмеологічної культури ${ }^{36}$ та ін.

Виклад основного матеріалу. Особлива увага дослідників прикута до вибору найдоцільніших методів навчання аспірантів. Так, Дж. Садлак (J. Sadlak) та А. Купфер (A. Kupfer) акцентують на доцільності одержання здобувачами глибинних міждисциплінарних знань, навичок ефективного використання дослідних методів, навичок критичного мислення; використанні методів, які спрямовані на формування навичок роботі у команді, лідерства, тайм менеджменту ${ }^{37}$. А. Демірболат (A. Demirbolat) доводить ефективність гармонійного поєднання теорії, практики й

31 Пшенична О.С. Компетентнісна парадигма підготовки здобувачів ступеня доктора філософії в галузі освіти. Педагогіка формування творчої особистості у вишій $i$ загальноосвітній школах. 2017. Вип. 56-57 (109-110). С. 343-349.

32 Меняйло В. Методологічні засади підготовки майбутніх докторів філософії до дослідницько-інноваційної діяльності. Збірник наукових праць Уманського державного педагогічного університету. 2020. Вип. 2. ч. 1. C. $106-120$.

33 Линьова І.О Оцінювання якості підготовки докторів філософії в контексті євроінтеграції. Аналіз провідного вітчизняного та зарубіжного досвіду щодо оцінювання якості вищої освіти в умовах євроінтеграції: аналітичні матеріали (частина I). За ред. В. Лугового, Ж. Таланової. Київ : Ін-т вищої освіти НАПН України, 2018. С. 157-167.

34 Олійник I.В. Використання інтерактивних технологій у процесі формування дослідницької компетенції майбутніх докторів філософії в умовах аспірантури. Вісник Глухівського національного педагогічного університету імені Олександра Довженка. 2018. Вип. 36. С. 59-67.

35 Бутенко Л.Л. Методологізація загальнопедагогічної підготовки майбутніх учителів та науково-педагогічних працівників в умовах трирівневої системи вищої освіти : автореф. дис. на здобуття наукового ступеня доктора пед. наук за спеціальністю 13.00.04 - теорія і методика професійної освіти; Державний заклад «Луганський національний університет імені Тараса Шевченка». Старобільськ, 2021. 45 с.

${ }^{36}$ Семеног О. Академічна культура - фундаментальний складник підготовки доктора філософії зі спеціальності 015 «Професійна освіта». Педагогічні науки: теорія, історія, інноваційні технологї. 2016. № 5 (59). С. 192-203.

37 Kwiek, M. (2004) Poland In J Sadlak Doctoral studies and qualification in Europe and the united states: status and prospects (pp. 119-133). URL: https://books.google.com.ua/books?id=wXwfEAAAQBAJ\&pg=PA209\&lpg=PA209 $\& \mathrm{dq}=\mathrm{J} .+$ Sadlak,+A.+Kupfer\&source=bl\&ots=M4mivBCLRj\&sig=ACfU3U2rQIqWd5221IXGBz5mRVUWA6MnQ\&hl=uk\&sa=X\&ved=2ahUKEwiqv8rB6IXzAh Xv_CoKHS-EDwAQ6AF6BAgDEAM\#v=onepage\&q=J.\%20Sadlak\%2C\%20A.\% 20Kupfer\&f=false (accessed: 9 September 2021). 
різноманітної самостійної роботи (мікрогрупової, групової), виконання проєктів ${ }^{38}$. С. Гордон (S. Gordon), Д. Олівер (J. Oliver) ${ }^{39}$ як один 3 популярніших методів серед здобувачів виокремлюють проблемно-орієнтоване навчання, аудиторні обговорення в малих та великих групах, симуляції, створення постерів, розроблення портфоліо, рефлексивне письмо. Важливим виявилися погляди Б. Колін (B. Colin) і Дж. Уілсона (J. Wilson) ${ }^{40}$ про те, що система цінностей аспірантів визначають спосіб їх включення у навчання, інтерпретацію досвіду і навчання через досвід ${ }^{41}$.

Для розкриття теми нашого дослідження варто взяти до уваги праці науковиів, які обтрунтовують різні аспекти проблеми підготовки аспірантів до написання та реалізаиії дисертаційного дослідження. Зазвичай вчені характеризують нормативні аспекти підготовки дисертаиії (В. Кондаков ${ }^{42}$ ); загальні основи підготовки аспірантів до навчання та наукових досліджень (К. О’Клер (K. O’Clair) ${ }^{43}$ ); рекомендації щзодо написання та оформлення результатів дисертащійної роботи (Дж. Коллінз (J. Collins) $\left.{ }^{44}\right)$; особливості подолання аспірантами письменницьких та емоційних викликів при написанні наукових публікащій (П. Карліно $\left.(\mathrm{P} . \text { Carlino })^{45}\right)$; шляхи підвищення якості підготовки аспірантів в рамках реалізації концепиіï проєктної діяльності (О.Гура,

${ }^{38}$ Demirbolat, A. (2005). Yüksek lisans öğrencilerinin programdan ve öğretim elemanlarından beklentileri. [The expectations of the post graduate students about the program and the academic staff]. Türk Eğitim Bilimleri Dergisi, 1 (3), 47-64.

${ }^{39}$ Gordon S.P., Oliver J. (2015). Examining the Value Master's and PhD Students. Place on Various Instructional Methods in Educational Leadership Preparation. International Journal of Educational Leadership Preparation, Vol. 10 (21), 77-98.

${ }^{40}$ Colin B. \& Wilson J. (2006). Experiential Learning: A Best Practices Handbook for Educators and Trainers. Philadelphia: Kogan Page.

${ }^{41}$ Colin B. \& Wilson J. (2006). Experiential Learning: A Best Practices Handbook for Educators and Trainers. Philadelphia: Kogan Page, P. 17.

42 Кондаков В.В. Нормативные аспекты подготовки диссертации на соискание ученой степени кандидата наук. Вестник Российской академии наук. 2018. T. 88. № 2. C. 118-129.

${ }^{43}$ O'Clair K. (2013). Preparing graduate students for graduate-level study and research. Reference Services Review, 41 (2), 336-350. URL: https://doi.org/10.1108/00907321311326255.

${ }^{44}$ Collins J. (2015). Writer's Forum - Writing for Publication While in Graduate School: An Accessible Reality. New Horizons in Adult Education \& Human Resource Development, 27 (1), 51-55.

${ }^{45}$ Carlino P. (2012). Helping Doctoral Students of Education to Face Writing and Emotional Challenges in Identity Transition. En Castello, M. y Donahue, C. University writing: Selves and Texts in Academic Societies, 2012. London (Reino Unido): Emerald Group Publ. 
В. Меняйло, Н. Коваленко, Н. Воронова ${ }^{46}$ ); роль освітньої складової підготовки докторів у галузі освіти як основи науково-педагогічного дослідження (О. Пшенична, Р. Клопов $\left.{ }^{47}\right)$; зміст та особливості викладання дисципліни «Управління науковими проєктами» (Т. Мамотова, Н. Рудік ${ }^{48}$ ). Незважаючи на багату численність досліджень, проблема підготовки майбутніх докторів філософії до написання та реалізації дисертаційного проєкту не була об 'єктом спеціального вивчення і дане питання на сьогодні залишається одними з пріоритетних, тому потребує подальшого вивчення.

Переконливим є погляд вищезазначених науковців на проблему, що досліджується, проте автори у своӥх прачях акцентують увагу саме на понятті «дисертаційне дослідження», не використовуючи при изьому дефініцію «дисертаційний проєкт». Для того щзоб розкрити сутність останнього $i$ розмежувати терміни «дисертаційне дослідження» $i$ «дисертачійний проєкт», звернемось до змісту поняття «проєкт».

Доцільно зауважити, що донедавна цією дефініцією послугувалися в технічній сфері, ототожнюючи іiі здебільшого із документацією визначеного об’єкта. Результати аналізу наукових праць $з$ проблеми дослідження свідчать про те, що до цього часу єдиного розуміння поняття «проєкт» у науковій літературі не існує (табл. 1).

46 Гура О.І., Меняйло В.І., Коваленко Н.М., Воронова Н.В. Шляхи підвищення якості підготовки аспірантів в рамках реалізації концепції проєктної діяльності у Запорізькому національному університеті. Підготовка докторів філософії (PhD) в умовах реформування вищої освіти: матер. Всеукр. наук.практ. конф. (Запоріжжя, 5-6 жовтня 2017 р.). Запоріжжя : Запорізький національний університет, 2017, С. 82-87.

${ }^{47}$ Пшенична О.С., Клопов Р.В. Освітня складова підготовки докторів (PhD) в галузі освіти як основа науково-педагогічного дослідження. Підготовка докторів філософії $(\mathrm{PhD})$ в умовах реформування вищої освіти: матер. Всеукр. наук.-практ. конф. (Запоріжжя, 5-6 жовтня 2017 р.). Запоріжжя : Запорізький національний університет, 2017, С. 164-167.

${ }_{48}$ Мамотова Т.В., Рудік Н.М. Зміст та особливості викладання дисципліни «Управління науковими проектами» за програмою підготовки докторів філософії спеціальності 074 «Публічне управління та адміністрування». Підготовка докторів філософії $(\mathrm{PhD})$ в умовах реформування вищої освіти: матер. Всеукр. наук.-практ. конф. (Запоріжжя, 5-6 жовтня 2017 р.). Запоріжжя : Запорізький національний університет, 2017, С. 207-211. 
Таблиця 1

Підходи науковців до визначення поняття «проскт»

\begin{tabular}{|c|c|}
\hline Визначення поняття «проєкт» & Автор \\
\hline $\begin{array}{l}\text { Цілеспрямоване, наперед пророблене і заплановане створення чи } \\
\text { модернізація фізичних об'єктів, технологічних процесів, } \\
\text { технічної та організаційної документації для них, матеріальних, } \\
\text { фінансових, трудових та інших ресурсів, а також управлінських } \\
\text { рішень та заходів з їхнього виконання }{ }^{49}\end{array}$ & $\begin{array}{l}\text { В. Аньшина, } \\
\text { О. Ільїна }\end{array}$ \\
\hline $\begin{array}{l}\text { Завдання, метою якого є досягнення певного неповторного за } \\
\text { своїми характеристиками та особливостями результату, що } \\
\text { здійснюється в заздалегідь визначений термін, в межах ліміту } \\
\text { необхідних ресурсів (фінансових, кадрових, матеріальних тощо) }{ }^{50}\end{array}$ & О. Зотов \\
\hline $\begin{array}{l}\text { Комплекс науково-дослідних, проектно-конструкторських, } \\
\text { соціально-економічних та інших заходів, пов'язаних ресурсами, } \\
\text { виконавцями та термінами, відповідно оформлених і спрямованих } \\
\text { на зміну об’єкта управління, що забезпечує ефективність } \\
\text { вирішення основних завдань і досягнення відповідних цілей за } \\
\text { певний період }{ }^{51}\end{array}$ & Л. Ричкіна \\
\hline $\begin{array}{l}\text { Цілеспрямована, обмежена в часі та ресурсах зміна системи, що } \\
\text { має визначені вимоги до якості результату, а також відрізняється } \\
\text { специфічністю організування та реалізації }\end{array}$ & М. Цогоєв \\
\hline $\begin{array}{l}\text { Цілеспрямована ідея, для досягнення якої наперед обумовлені дії } \\
\text { виконуються визначеною командою у часових межах, що } \\
\text { характеризують її початок і кінець, використовуючи при цьому } \\
\text { обмежені ресурси та досягаючи встановлених ідеєю результатів }{ }^{53}\end{array}$ & С. Шарохіна \\
\hline
\end{tabular}

Аналізуючи наведені дефініції, констатуємо, що поняття «проєкт» розглядається багатоаспектно, а саме як процес, вид діяльності, сукупність певних дій, операційний документ, управлінський інструмент тощо. Різні визначення даного поняття як суперечать одне одному, так і доповнюють одне одного. Поділяємо думку М. Цогоєва, що сьогодні найбільш часто послуговуються

49 Аньшина В.М., Ильина О.Н. Управление проектами: фундаментальный курс. Москва : Высшая школа экономики, 2013. С. 13.

50 Зотов О.В. Проект, управління проектом: основні поняття, суб'єкти державного управління. Державне управління: удосконалення та розвиток. 2010. C. 98. URL: http://www.dy.nayka.com.ua/?op=1\&z=171 (дата звернення: 20 серпня 2021).

51 Ричкіна Л. Тенденції та перспективи застосування проектного менеджменту для розвитку територіальних громад. Ефективність державного управління. 2015. № 44. С. 178-184, 179.

52 Цогоев М.М. Современные подходи к определению понятия «управление проектами». Инновациионная наука. 2016. № 4. С. 94-98, 96.

53 Шарохина С.В. О сущности понятия «инвестиционный проект». Отходы и ресурсы. 2018. № 1. T. 5. URL: https://resources.today/PDF/03ECOR118.pdf (дата звернення: 23 серпня 2021). 
дефініціями, які базуються на системному (проєкт - система тимчасових дій, спрямованих на досягнення унікального і водночас визначеного результату) або діяльнісному (проєкт - конкретні дії, що спрямовані на досягнення встановлених цілей) підходах.

Вищезазначені визначення переконують у тому, що проєкт спрямований на досягнення неповторного, але в той же час певного результату; створення унікальних продуктів $i$ послуг до встановленого терміну. Своєю чергу наукове дослідження - че діяльність, спрямована на всебічне вивчення об'єкта, процесу або явища, їх структури $i$ зв'язків, а також отримання $i$ впровадження в практику корисних для людини результатів ${ }^{54}$. С очевидним, що дисертаційний проєкт передбачає проведення конкретного наукового дослідження.

Таким чином, аналіз наукової літератури, педагогічних i дисертаційних досліджень, сформована практика проєктної діяльності в сфері освіти та у науковій діяльності, власний досвід дозволяють виділити протиріччя між об'єктивною затребуваністю сфери професійної освіти у дослідниках, здатних до написання i реалізації власного дисертаційного проєкту, та недостатнім рівнем розробленості теоретико-методологічних основ, методикопедагогічних аспектів означеної підготовки в умовах аспірантури.

На основі результатів аналізу понятійно-категоріального апарату 3 досліджуваної проблеми, підходів до визначення сутності підготовки до проєктної діяльності, з урахуванням особливостей об'єкта нашого дослідження уточнено поняття «підготовка до написання і реалізації дисертаційного проєкту», яке визначається як система змістовно-педагогічних та організаційно-методичних заходів, реалізація яких забезпечує формування готовності майбутнього доктора філософії до написання i реалізації дисертаційного проєкту.

У даній роботі представлено хід та результати пілотного дослідження, яке проходило в період 325 травня по 25 червня 2020 року і було спрямоване на те, щоб: з'ясувати уявлення сучасних аспірантів та науково-педагогічних працівників щодо особливостей підготовки майбутніх докторів філософії до написання і реалізації дисертаційного проєкту в умовах аспірантури; визначити методи i

54 Огурцов А.Н. Основы научных исследований: учеб.-метод. пособ. Харьков, НТУ «ХПИ», 2008. 178 с. 
форми, що сприяють ефективній підготовці аспірантів до написання і реалізації дисертаційного проєкту.

Пілотне дослідження проводилось у формі опитування аспірантів та науково-педагогічних працівників, які здійснюють підготовку майбутніх докторів філософії (PhD). На кафедрі інноваційних технологій 3 педагогіки, психології та соціальної роботи ВНЗ «Університет імені Альфреда Нобеля» було розроблено анкету «Підготовка до написання і реалізації дисертаційного проєкту як важлива складова професійної діяльності майбутнього доктора філософії». В анкеті були представлені 8 питань, які спрямовані на виявлення уявлень респондентів щодо сутності поняття «дисертаційний проєкт»; визначення ключових компетентностей, які повинні бути сформовані у аспірантів для успішного написання i реалізації дисертаційного проєкту; уточнення форм і метод, які ефективно сприяють підготовці майбутніх докторів філософії до написання і реалізації дисертаційного проєкту; а також виявлення рівня зацікавленості аспірантів і науково-педагогічних працівників проблемою, яка порушується в анкеті.

Дослідження проводилось шляхом онлайн-анкетування респондентів за допомогою сервісів Google. Участь у дослідженні взяло 108 осіб, з яких 61 осіб (56,5\%) - науково-педагогічні працівники, $47(43,5 \%)$ - аспіранти. Більшість опитаних 63 учасники $(58,3 \%)$ є представниками освітньо-наукових програм галузі знань 01 Освіта/Педагогіка (015 Професійна освіта (за спеціалізаціями), 011 Освітні, педагогічні науки), 23 (21,3\%) освітньо-наукових програм галузі знань 07 Управління та адміністрування (072 Фінанси, банківська справа та страхування, 073 Менеджмент, 076 Підприємництво, торгівля та біржова діяльність), 12 (11,1\%) - освітньо-наукових програм галузі знань 05 Соціальні та поведінкові науки (051 Економіка, 053 Психологія, 054 Соціологія), 6 (5,6 \%) - освітньо-наукових програм галузі знань 23 Соціальна робота (231 Соціальна робота), 4 (3,7 \%) - освітньонаукових програм галузі знань 03 Гуманітарні науки (035 Філологія).

Як було відзначено, в терміни з 25 травня по 25 червня 2020 року нами було проведено пілотне дослідження, в якому взяли участь 108 респондентів, отже, подальший виклад матеріалу буде присвячено підведенню підсумків означеного дослідження. 3 огляду на те, що пілотне дослідження не спрямоване на отримання змістовних даних, а лише орієнтовано на виявлення уявлень респондентів щодо особливостей підготовки майбутніх докторів 
філософії до написання і реалізації дисертаційного проєкту, то цей етап був присвячений виявленню можливих проблем i/aбо особливостей підготовки аспірантів до написання i реалізації дисертаційного проєкту, а аналіз результатів пілотного дослідження спрямований на виявлення можливостей для вдосконалення професійної підготовки майбутніх докторів філософії в умовах аспірантурі засобами проєктного управління.

У межах опитування аспірантам та науково-педагогічним працівникам було запропоновано заповнити онлайн-анкету, що містила питання відкритого та закритого типу щодо різних аспектів проблеми підготовки до написання i реалізації дисертаційного проєкту в аспірантурі.

Питання 1. Чи згодні Ви з наступною тезою: «Підготовка докторів філософії до написання і реалізачії дисертащійного проєкту є важливим складником професійної діяльності майбутнього доктора piлософiї». Більшість опитуваних згодні (80 осіб) і скоріше згодні, ніж ні (28 осіб), з тезою, що підготовка докторів філософії до написання і реалізації дисертаційного проєкту $\epsilon$ важливим складником професійної діяльності майбутнього доктора філософії.

Питання 2. Що, на Вашу думку, означає поняття «дисертаиійний проєкт»? Щодо відповіді на це питання, то 54 учасника визначили його як дослідження, орієнтоване на отримання об'єктивно нового результату; 35 учасників акцентували увагу на тому, що особливостями дисертаційного проєкту $\epsilon$ координовані та контрольовані роботи з датами початку та закінчення, які виконуються для досягнення мети дослідження; 15 осіб як основної риси дисертаційного проєкту зазначили опис конкретної ситуації, яка має бути поліпшена, і конкретних методів щодо ії поліпшення; 4 учасники опитування не дали чіткої відповіді на питання.

Питання 3. Як Ви оцінюєте сучасний рівень підготовки докторів філософії до написання і реалізації дисертаційного проєкту в Україні? Ми отримали наступні результати: сучасний рівень підготовка докторів філософії до написання і реалізації дисертаційного проєкту оцінили як високий - 22 осіб; достатній - 41 осіб; середній - 38 особи; низький -6 осіб і дуже низький - 1 особа.

Питання 4. Зазначте фактори, від яких, на Вашу думку, залежить ефективність написання і реалізації дисертаційного проєкту. Оберіть декілька варіантів з числа пропонованих. Інформація щодо відповідей респондентів на це питання наведена у табл. 2. 
Таблиця 2

Розподіл відповідей на питання: «Зазначте фактори, від яких, на

Вашу думку, залежить ефективність написання і реалізації дисертаційного проєкту» (можливо декілька варіантів відповіді)

\begin{tabular}{|c|c|c|c|c|c|}
\hline \multirow[t]{2}{*}{ № } & \multirow[t]{2}{*}{ Варіанти відповідей } & \multicolumn{2}{|c|}{ Аспіранти } & \multicolumn{2}{|c|}{$\begin{array}{c}\text { Науково- } \\
\text { педагогічні } \\
\text { працівники } \\
\end{array}$} \\
\hline & & K-Tb & $\%$ & К-ть & $\%$ \\
\hline 1. & $\begin{array}{c}\text { Досвід наукової, педагогічної } \\
\text { і проєктної діяльності }\end{array}$ & 36 & 76,6 & 43 & 70,5 \\
\hline 2. & $\begin{array}{c}\text { Підтримка наукового } \\
\text { керівника, колег, сім’ ї тощо }\end{array}$ & 45 & 95,7 & 40 & 65,6 \\
\hline 3. & $\begin{array}{c}\text { Досягнення найкращих } \\
\text { результатів за менший } \\
\text { проміжок часу }\end{array}$ & 27 & 57,4 & 45 & 73,8 \\
\hline 4. & $\begin{array}{c}\text { Створення банку ідей } \\
\text { і результатів дисертаційного } \\
\text { проєкту, який повинен } \\
\text { включати ідеальний, реальний } \\
\text { продукт, що володіє } \\
\text { об’єктивною новизною } \\
\end{array}$ & 22 & 46,8 & 53 & 86,9 \\
\hline 5. & $\begin{array}{c}\text { Наявність обгрунтованого } \\
\text { плану дій щодо роботи над } \\
\text { дисертаційним проєктом }\end{array}$ & 15 & 31,9 & 51 & 83,6 \\
\hline 6. & $\begin{array}{c}\text { Відслідковування виконання } \\
\text { етапів дисертаційного проєкту } \\
\text { у встановлені терміни та } \\
\text { витрати ресурсів } \\
\end{array}$ & 32 & 68,0 & 34 & 55,8 \\
\hline 7. & $\begin{array}{c}\text { Ефективна взаємодія зі } \\
\text { стейкхолдерами } \\
\text { дисертаційного проєкту }\end{array}$ & 37 & 78,7 & 58 & 95,1 \\
\hline 8. & $\begin{array}{c}\text { Атмосфера інтенсивного } \\
\text { обміну інформацією } \\
\text { і відкритої комунікації }\end{array}$ & 44 & 93,6 & 56 & 91,8 \\
\hline
\end{tabular}

Питання 5. Проранжуйте ключові за рівнем значущості компетентності, які повинні бути сформовані у аспірантів для успішного написання $i$ реалізації дисертаційного проєкту. Результати ранжування учасниками опитування ключових компетентностей представлено на рис. 1. 
Ефективно контролювати хід реалізації дисертаційного проєкту та управляти можлпвімп змкінамп цього процесу

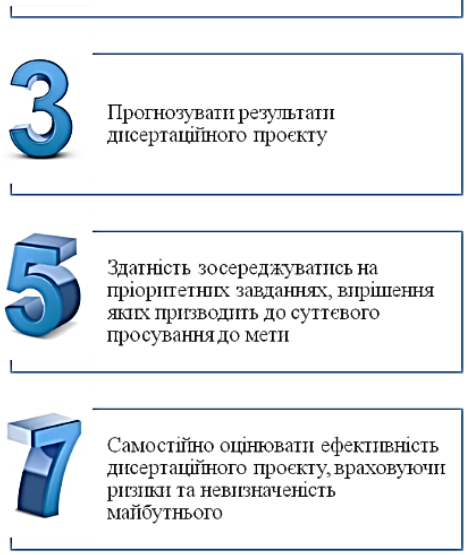

Визначати і обгрунтовувати юргдигні, фінансово-економпіні, техніко-технологічні, соціальні, екологічні показнгки дисертаційного проєкту

Ставпти і внрішувати завдання із структургзації, сгнхронізації, коордшнаціі та інтеграції процесів під час роботи над дисертаційнтм проєКТОМ

Здатність швгдко реагувати на змінш й адаптуватнсь до нгх; здатність долати труднощі

Вıконувати техніко-економічн обгрунтування днсертаційного проєкту, враховуюшг зовнішті ЧIHHIIKI

Рис. 1. Ранжування за рівнем значущості компетентностей, які повинні бути сформовані у аспірантів для успішного написання і реалізації дисертаційного проскту

Питання 6. Виберіть з числа перерахованих форм і метод ті, які ефективно сприяють підготовиі майбутніх докторів філософії до написання $i$ реалізаиії дисертаційного проєкту. Найбільш ефективними формами i методами підготовки до написання i реалізації дисертаційного проєкту 3 числа запропонованих респонденти вважають:

- конкурси науково-дослідних проєктів (українські, міжнародні);

- клуб аспірантів і докторантів;

- конкурси на здобуття премії/стипендії Президента України, Кабінету Міністрів України, Верховної Ради України для молодих учених;

- участь у виконанні науково-дослідних тем кафедр; 
- участь у програмах міжнародної академічної мобільності (в Україні і закордоном);

- тренінги із фандрайзингу та проєктного менеджменту;

- щорічні конкурси «Молодий вчений року», «Молодий вчений Дніпропетровщини» тощо;

- всеукраїнські, регіональні, міжнародні науково-практичні конференції (очна або дистанційна участь);

- засідання груп із забеспечення якості вищої освіти;

- конкурсний відбір експертів Національного Агентства із забезпечення якості вищої освіти з числа студентства (студенти й аспіранти);

- підготовка заявок на отримання свідоцтва про реєстрацію авторського права на твір;

- участь у проведенні науково-методичних семінарів, конференцій кафедри, університету;

- проведення моніторингового дослідження за тематикою дисертаційного проєкту;

- пошук грантових конкурсів, оцінювання умов отримання фінансування;

- підготовка і реалізація групових соціально важливих проєктів в межах університету;

- участь у реалізації дослідницьких, освітніх, соціальних проєктів на міському, обласному, державному та міжнародному рівнях;

- збір первинної інформації (опитування, спостереження, особисті інтерв'ю, дискусії у фокус-групах 3 потенційними респондентами тощо);

- стажування (навчання) в закордонному закладі освіти або дослідницькій лабораторії;

- зустрічі з фахівцями, які мають досвід проєктної діяльності в галузі освіти та науки;

- написання статей, монографій, тез доповідей, навчальних посібників тощо;

- викладацька практика;

- розробка індивідуальної освітньої траєкторії.

Питання 7. Які освітні компоненти Вамої освітньо-наукової програми сприяють підготовці до написання $i$ реалізачії дисертаційного проєкту? Думки респондентів відображені на рис. 2. 


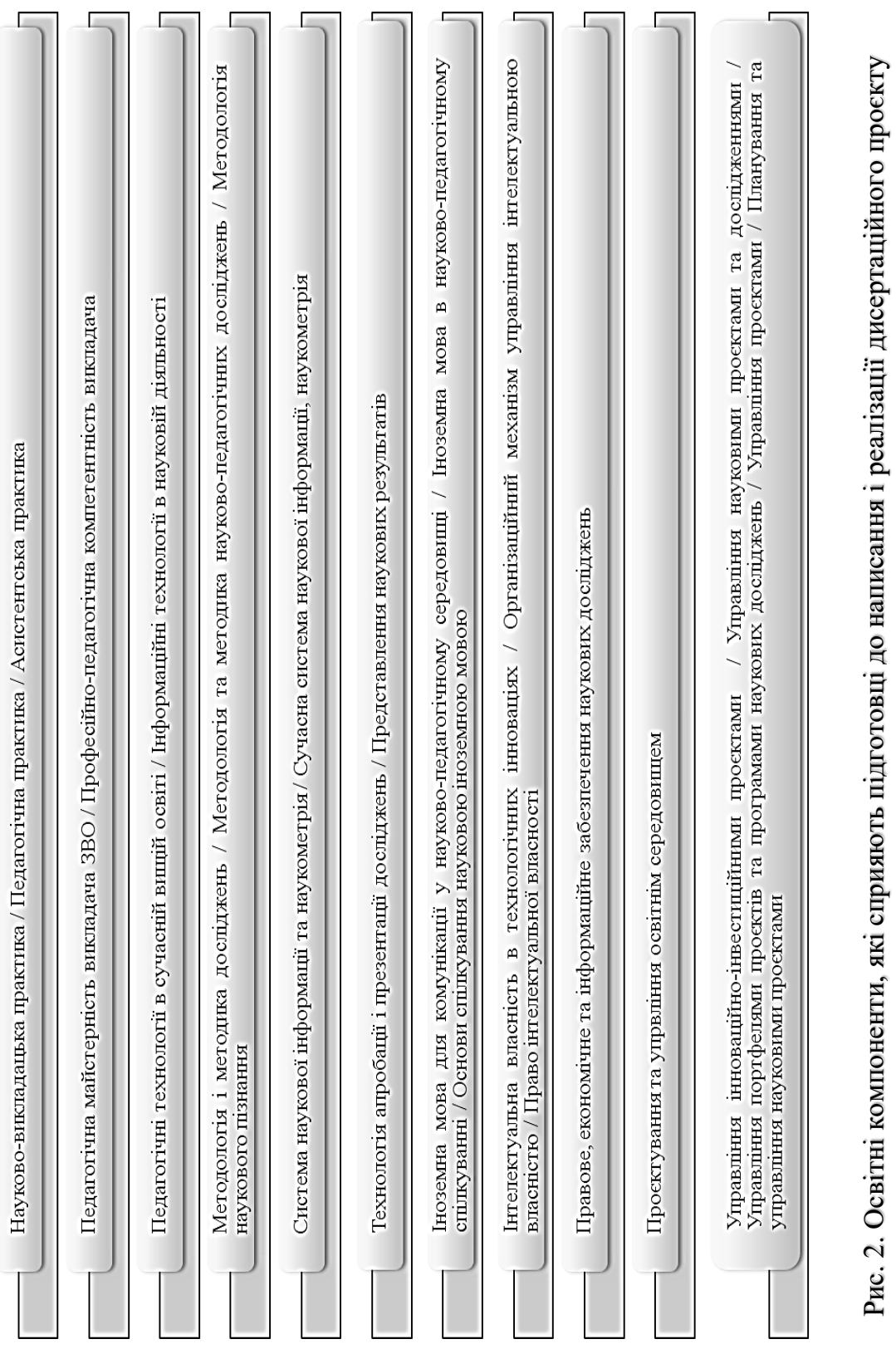


Питання 8. Які навчальні дисичилліни Ви б рекомендували включити до освітньо-наукової програми з метою вдосконалення підготовки аспірантів до написання $i$ реалізащиї дисертаційного проєкту?». Оскільки відповіді на це питання дуже різнилися, ми об'єднали їх за близьким змістом у декілька узагальнених назв, представлених у табл. 3.

Враховуючи дані пілотного дослідження, можна зробити висновок, що здобувачі вищої освіти третього (освітньо-наукового) рівня та науково-педагогічні працівники в цілому згодні з тим, що підготовка докторів філософії до написання та реалізації дисертаційного проєкту $є$ важливим складником професійної діяльності майбутнього доктора філософії, проте рівень цієї підготовки в Україні вони визначають як достатній та середній. Більшість опитаних розуміють зміст поняття «дисертаційний проєкт» та визначають його як дослідження орієнтоване на отримання об'єктивно нового результату.

При відповіді на запитання щодо факторів, від яких залежить ефективність написання та реалізації дисертаційного проєкту, думки аспірантів і викладачів були однозначні. Так, для здобувачів вищої освіти важливими факторами є: 1) підтримка наукового керівника, колег, сім'ї тощо; 2) атмосфера інтенсивного обміну інформацією i відкритої комунікації; 3) ефективна взаємодія зі стейкхолдерами дисертаційного проєкту. Науково-педагогічні працівники серед трьох основних факторів виділяють такі: 1) ефективна взаємодія зі стейкхолдерами дисертаційного проєкту; 2) атмосфера інтенсивного обміну інформацією і відкритої комунікації; 3) створення банку ідей i результатів дисертаційного проєкта, який повинен включати ідеальний, реальний продукт, що володіє об 'єктивною новизною.

Результати пілотного дослідження підтверджують, що загалом респонденти розуміють важливість підготовки майбутніх докторів філософії до написання та реалізації дисертаційного проєкту, тому це питання потребує грунтовного аналізу та висновків щодо змісту, форм і методів означеної підготовки.

Розкриємо особливості підготовки до написання та реалізації дисертаційного проєкту майбутніх докторів філософії, які навчаються за освітньо-науковою програмою «Професійна освіта» ${ }^{55}$, спеціальність 015 Професійна освіта (за спеціалізаціями).

55 Освітньо-наукова програма «Професійна освіта» підготовки здобувачів третього (освітньо-наукового) рівня за спеціальністю 015 Професійна освіта (за спеціалізаціями) галузі знань 01 Освіта/Педагогіка. Дніпро : Університет імені Альфреда Нобеля, 2021. 26 с. URL: https://duan.edu.ua/images/head/ QualityEdu/OPPdrafts/2021/Final/prof_osv_2021-prog.pdf (дата звернення: 25.09.2021 p.) 
Таблиця 3

Результати відповіді на запитання «Які навчальні дисципліни Ви б рекомендували включити до освітньо-наукової програми з метою вдосконалення підготовки аспірантів до написання і реалізації дисертаційного проєкту?»

\begin{tabular}{|c|c|c|}
\hline № & Назва навчальної дисципліни & K-Tb \\
\hline \multirow{4}{*}{1.} & Робота над дисертаційним проєктом & \multirow{4}{*}{78} \\
\hline & Управління дисертаційним проєктом & \\
\hline & Планування та управління науковими проєктами & \\
\hline & Підготовка та керівництво науковими проєктами & \\
\hline \multirow{3}{*}{2.} & Управління проєктом як наука & \multirow{3}{*}{43} \\
\hline & Теорія і практика управління проєктами в освіті & \\
\hline & Проєктна діяльність в галузі освіти і науки & \\
\hline \multirow{2}{*}{3.} & Професійно-педагогічна комунікація & \multirow{2}{*}{57} \\
\hline & Тренінг комунікативності й особистісного розвитку & \\
\hline \multirow{3}{*}{4.} & Технології фандрайзинга & \multirow{3}{*}{31} \\
\hline & Фандрайзинг в освіті та науці & \\
\hline & Основи наукового фандрайзингу & \\
\hline \multirow{3}{*}{5.} & Просування наукового контенту & \multirow{3}{*}{28} \\
\hline & Право інтелектуальної власності & \\
\hline & Реєстрація та захист прав інтелектуальної власності & \\
\hline \multirow[b]{2}{*}{6.} & Дисертаційний менеджмент & \multirow[b]{2}{*}{8} \\
\hline & $\begin{array}{c}\text { Правове, економічне та інформаційне забезпечення } \\
\text { наукових досліджень }\end{array}$ & \\
\hline
\end{tabular}

Перш за все зазначимо, що означену освітньо-наукову програму розроблено й упроваджено у ВНЗ «Університет імені Альфреда Нобеля» у 2016 році. Протягом чотирьох років освітньо-наукова програма уточнювалася задля забезпечення освітніх потреб майбутніх докторів філософії, створення їх індивідуально-освітніх траєкторій 3 урахуванням рекомендацій Національного агентства із забезпечення якості вищої освіти, академічної спільноти, стейкхолдерів, аспірантів.

Сьогодні метою освітньо-наукової програми «Професійна освіта» $\epsilon$ підготовка висококваліфікованих науково-педагогічних кадрів, здатних до дослідницько-інноваційної, науково-педагогічної, проектної діяльності, якісного супроводження освітнього процесу та креативного розв'язання актуальних проблем у сфері професійної освіти, проведення та успішного завершення наукового дослідження i подальшої професійно-наукової діяльності, що $є$ основою їх конкурентоспроможності на ринку праці в Україні та за ії межами.

Вона спрямована на набуття майбутніми науковцями інтегральних, загальних та спеціальних компетентностей щодо здійснення 
інноваційної викладацької, психолого-педагогічної, проектної, науководослідної й управлінської діяльності у 3ВО; оволодіння компетентностями викладача ЗВО, здатного здійснювати, формулювати і розв'язувати комплексні наукові й практичні проблеми професійної освіти, успішно працювати та бути конкурентоспроможним на ринку праці ${ }^{56}$.

Зупинимося на особливостях підготовки майбутніх докторів фiлософiї до написання та реалізації дисертаційного проєкту в контексті освітньо-наукової програми «Професійна освіта», яка реалізується у ВНЗ «Університет імені Альфреда Нобеля». Маємо підкреслити, що моделювання змісту освітньо-наукової програми передбачало включення саме тих навчальних дисциплін, зміст яких допомагав би здобувачам у написанні та реалізації дисертаційного проєкту. Перелік компонентів освітньо-наукової програми «Професійна освіта» подано у табл. 4.

Перед викладом кожної навчальної дисципліни викладач знайомиться із темами дисертаційних досліджень аспірантів даної групи і моделює зміст кожного заняття, максимально акцентуючи увагу на тих питаннях, які $є$ вагомими для написання дисертаційного проєкту. Крім зазначеного, розкриваючи окремі питання дисципліни викладачі наводять приклади, складають кейсові завдання, базуючись на змісті захищених дисертацій в разових спеціалізованих радах ВНЗ «Університет імені Альфреда Нобеля».

Так, під час вивчення теми «Теоретико-методологічні основи технологіі педагогічного наукового дослідження» (навчальна дисиипліна «Технологія педагогічного наукового дослідження») лектор, на прикладі дисертації, яку було захищено в разовій спеціалізованій раді ВНЗ «Університету імені Альфреда Нобеля», наочно демонстрував методи педагогічного наукового дослідження, які було використано в роботі випускницею освітньо-наукової програми «Професійна освіта» (рис. 3).

56 Волкова Н.П., Лебідь О.В. 3 досвіду впровадження освітньо-наукової програми «Професійна освіта» для здобувачів третього (освітньо-наукового) рівня вищої освіти спеціальності 015 Професійна освіта (за спеціалізаціями). Вісник університету імені Альфреда Нобеля: Серія Педагогіка і психологія. Педагогічні науки. Дніпро : ТОВ «Роял Принт», 2021. Вип. 1 (21). С. 127-140. 
Таблиця 4

Перелік компонент освітньо-наукової програми «Професійна освіта» та їх логічна послідовність

\begin{tabular}{|c|c|c|c|}
\hline Код о/к & $\begin{array}{c}\text { Компоненти освітньо-наукової } \\
\text { програми (навчальні } \\
\text { дисципліни, проекти, практики) }\end{array}$ & $\begin{array}{c}\text { Кількість } \\
\text { кредитів }\end{array}$ & $\begin{array}{c}\text { Форма } \\
\text { підсумк. } \\
\text { контролю }\end{array}$ \\
\hline \multicolumn{4}{|c|}{ Обов'язкові компоненти освітньо-НАУКОВої програми } \\
\hline \multicolumn{4}{|c|}{ Обов'язкові загальні компоненти ОЗК (01) } \\
\hline ОЗК 1 & $\begin{array}{c}\text { Філософія науки і методи наукових } \\
\text { досліджень }\end{array}$ & 4,5 & екзамен \\
\hline O3К 2 & Іноземна мова для академічних цілей & 6 & екзамен \\
\hline OЗК 3 & $\begin{array}{c}\text { Педагогічні технології в сучасній } \\
\text { вищій освіті }\end{array}$ & 4,5 & екзамен \\
\hline \multicolumn{4}{|c|}{ Обов'язкові професійні компоненти ОПК (02) } \\
\hline ОПК 1 & $\begin{array}{c}\text { Психологія педагогічної діяльності } \\
\text { викладача закладу вищої освіти }\end{array}$ & 4 & екзамен \\
\hline ОПК 2 & $\begin{array}{c}\text { Управління проєктами в сфері } \\
\text { освіти }\end{array}$ & 3 & залік \\
\hline ОПК 3 & $\begin{array}{c}\text { Професійно-педагогічна } \\
\text { комунікація } \\
\end{array}$ & 3 & залік \\
\hline ОПК 4 & Педагогічна майстерня & 3 & залік \\
\hline ОПК 5 & Науково-викладацька практика & 4,5 & залік \\
\hline & $\begin{array}{c}\text { Загальний обсяг обов'язкових } \\
\text { компонент: }\end{array}$ & \multicolumn{2}{|c|}{ 32,5 кред. /975 годин } \\
\hline \multicolumn{4}{|c|}{ Вибіркові компоненти освітньо-наукової програми } \\
\hline \multicolumn{4}{|c|}{ Вибіркові загальні компоненти ВЗК (01) } \\
\hline ВЗК 1 & $\begin{array}{c}\text { Інноваційні педагогічні системи } \\
\text { XXI ст. }\end{array}$ & 3 & екзамен \\
\hline В3К 2 & Основи андрагогіки & & \\
\hline \multicolumn{4}{|c|}{ Вибіркові професійні компоненти ВПК (02) } \\
\hline ВПК 1 & $\begin{array}{c}\text { Педагогічна майстерність } \\
\text { викладача закладу вищої освіти }\end{array}$ & 3 & залік \\
\hline ВПК 2 & $\begin{array}{c}\text { Підготовка, апробація та } \\
\text { презентація результатів } \\
\text { дисертаційного дослідження }\end{array}$ & & \\
\hline ВПК 3 & $\begin{array}{c}\text { Технологія педагогічного } \\
\text { наукового дослідження }\end{array}$ & & \\
\hline ВПК 4 & Академічне письмо та риторика & 3 & екзамен \\
\hline ВПК 5 & Фандрайзинг в освітній діяльності & & \\
\hline ВПК 6 & $\begin{array}{c}\text { Самоменеджмент та саморозвиток } \\
\text { викладача закладу вищої освіти }\end{array}$ & 3,5 & залік \\
\hline ВПК 7 & $\begin{array}{l}\text { Рефлексія особистісно- } \\
\text { професійного розвитку }\end{array}$ & & \\
\hline & $\begin{array}{c}\text { Загальний обсяг вибіркових } \\
\text { компонент: }\end{array}$ & \multicolumn{2}{|c|}{ 12,5 кред. /375 годин } \\
\hline & $\begin{array}{c}\text { ЗАГАЛЬНИЙ ОБСЯГ компонент } \\
\text { освітньо-наукової програми }\end{array}$ & \multicolumn{2}{|c|}{45 кред./1350 годин } \\
\hline
\end{tabular}


Проілюструємо викладене явище яскравими прикладами.

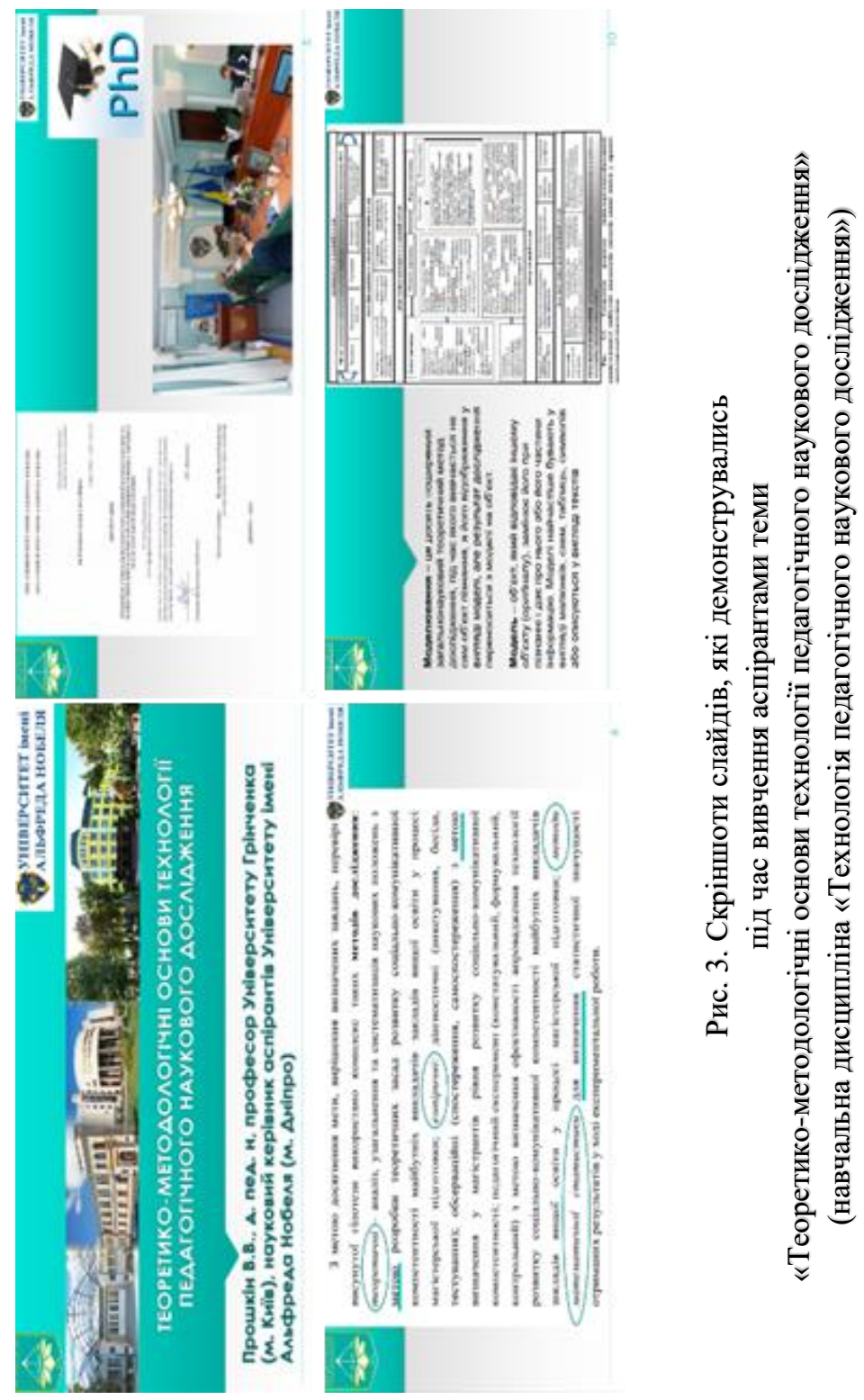


Ураховуючи результати пілотного дослідження, нами було прийнято рішення до обов'язкових професійних компонентів освітньо-наукової програми додати навчальний курс «Управління проєктами в сфері освіти», а перелік вибіркових професійних компонентів збагатити навчальною дисципліною «Фандрайзинг в освітній діяльності».

Розглянемо більш детально можливості цих навчальних курсів у процесі підготовки майбутніх докторів філософії до написання та реалізації дисертаційного проєкту.

Метою викладання навчальної дисципліни «Управління проєктами в сфері освіти» $\epsilon$ формування у здобувачів третього (освітньо-наукового) рівня вищої освіти необхідних теоретичних знань і практичних навичок з методології управління проєктами, яка $\epsilon$ перспективним напрямом розвитку системи освіти, а також опанування відповідного інструментарію для успішного управління проєктами як ефективного фактору істотного підвищення результативності науково-дослідницької та викладацької діяльності.

Під час вивчення дисципліни вирішуються такі основні завдання: забезпечити засвоєння сутності системного підходу до управління проєктами в сфері освіти та набуття навичок 3 управління проєктами при ініціації, розробці та реалізації проєктів у науково-дослідницькій та викладацькій діяльності; дати можливість оволодіти методами управління проєктами на всіх фазах життєвого циклу проєкту; навчити застосовувати набуті знання $з$ управління проєктами у процесі здійснення науководослідницької та викладацької діяльності.

3 метою забезпечення ефективної проєктної діяльності аспірантів під час викладання навчальної дисципліни «Управління проєктами в сфері освіти» створюється проєктно-орієнтоване освітнє середовище як система розвиваючих можливостей, забезпечена відповідними ресурсами $^{57}$. В якості таких ресурсів виступили як педагогічні методи та технології викладання і навчання (студентоцентроване та проблемно-орієнтоване навчання, діалогічно-дискусійні технології (проблемна лекція-діалог, дискусія, диспут, метод мозкового штурму), пошук інтернет-інформації, есе (за темою індивідуального практичного завдання), аналіз конкретних ситуацій (case study), робота в мікро-групах, тренінг, метод проєктів (міні-проєкти), тощо),

57 Ясвин В.А. Образовательная среда: от моделирования к проектированию. Москва : Смысл, 2001. 365 с. 
так і специфічні методи і засобів проєктування та управління проєктами (схематизація, метод Agile, Lean (метод «лін»), Scrum (метод «скрам»), діаграма Ганта, моделювання, метод експертної оцінки, метод критичного шляху, тощо). Формами організації навчання стали: тренінг і проєкт.

Так, під час вивчення дисципліни аспіранти розробили та реалізували в межах ВНЗ «Університет імені Альфреда Нобеля» груповий проєкт сприяння академічній доброчесності. Його мета донести до студентської спільноти значення академічної доброчесності та наслідки недотримання іiі постулатів. Майбутні доктори філософії провели відкриті лекції, на яких учасники проєкту отримали практичні знання і навички щодо впровадження основних принципів академічної доброчесності, плану дій щодо їх популяризації серед студентства.

Створене проєктно-орієнтоване освітнє середовище під час вивчення навчальної дисципліни «Управління проєктами в сфері освіти» забезпечувало поетапне освоєння аспірантом інструментарію розробки, реалізації та оцінки освітньо-наукового проєкту в процесі його виконання. В рамках навчання дослідники розробляли і реалізували міні-проєкти (складові дисертаційного проєкту), спрямовані на вирішення реальних професійно-педагогічних проблем.

Наступною важливою дисципліною, яка забезпечує підготовку аспірантів до управління дисертаційним проєктом, $є$ «Фандрайзинг в освітній діяльності». Мета дисципліни - забезпечити загальну теоретичну й практичну підготовку здобувачів третього (освітньонаукового) рівня вищої освіти з питань сутності фандрайзингової діяльності у сфері освіти, яка слугуватиме основою для здійснення ними планування фандрайзингової кампанії, прогнозування результатів наукових і освітніх проєктів, залучення ресурсів донорів у галузі професійної та/або дослідницько-інноваційної діяльності. Завданнями навчального курсу $\epsilon$ : опанувати знаннями про особливості організації фандрайзингової кампанії, іiї планування, реалізацію та оцінювання ефективності; формувати цілісне уявлення про фандрайзинг як практику залучення коштів на освітні та дослідні проєкти; обгрунтовано обирати i ефективно використовувати технології пошуку та постійної роботи потенційних донорів; розвивати вміння використовувати інструменти фандрайзингу в професійній діяльності.

Під час вивчення цієї дисципліни аспіранти знайомляться 3 проєктами, які пропонує Університет імені Альфреда Нобеля; вивчають 146 
Інтернет-сайти фондів і організацій, на яких регулярно публікуються оголошення про надання грантів на дослідження, наукові проєкти або фінансування інновацій; практикуються грамотно складати заявку, план, опис власного дисертаційного проєкту.

Невід'ємним елементом стала пошукова дослідницька діяльність аспірантів засобами інформаційних технологій, самопідготовка в бібліотеці та за допомогою Інтернет, інформаційна підтримка здобувачів. Здобувачі завдяки наданому доступу до наукометричних баз: Scopus, Web of Science, Directory of Open Access Journals, Index Copernicus, РІНЦ, Google Scholar, мали можливість ознайомитися 3 науковою літературою для виконання міні-проєктів в рамках дисертаційного дослідження. Крім зазначеного, так як Університет сертифікований та акредитований міжнародними організаціями: ZEvA, ECBE, ISO 9001:2015, аспіранти мали доступ до он-лайн ресурсів бібліотеки Університету Уельсу Святої Трійці та Святого Давида, міжнародної бібліотеки HEDBIB (https://hedbib.iau-aiu.net/home.php).

Зазначимо, що елементи досліджень аспірантів використовуються в освітній діяльності. Як приклади зазначимо: підготовку дослідницьких, пошукових проєктів, під час здійснення яких аспіранти аналізують статті фахових виданнях, зокрема індексованих у базах даних Scopus та/або Web of Science Core Collection, розробляють моделі, технології, педагогічні умови, методи, засоби, які можуть використовуватися ними для подальшої роботи за темою дисертаційного дослідження; підготовку публікацій у збірниках, які видаються за результатами проведення наукових або професійних заходів (конференцій, науковопрактичних семінарів, тренінгів, вебінарів тощо).

Наукові досягнення здобувачів вищої освіти знаходили відображення в освітньому процесі Університету. Викладачами кафедри було перевірено на практиці ефективність технології розвитку соціально-комунікативної компетентності майбутніх викладачів закладу вищої освіти у процесі магістерської підготовки (концептуальний, мотиваційно-стимулюючий, змістовопроцесуальний, практичний, діагностико-корекційний), яка була розроблена аспіранткою Л. Верченко. Розробки здобувачки впроваджено у позааудиторну роботу магістрантів («Психологічна майстерня» (тренінги-семінари, тренінги психологічно доцільних технологій, Skype майстер-класи) (довідка про впровадження № 35/1 від 13.01 .2020 р.). Макхулі Іхабом розроблено дисципліну за вибором «Поліетнічний освітній простір», метою якої є формування готовності до роботи в умовах поліетнічного освітнього середовища. Апробація у 
процесі підготовки майбутніх філологів у 2018-2019 н.р. (довідка про впровадження № 35/2 від 13.01.2020 р.). В. Шараварою у 2018-2021 н.р. на базі Університету імені Альфреда Нобеля упроваджено авторську педагогічну технологію формування прогностичної компетентності майбутніх бакалаврів комп'ютерних наук, авторську навчальну дисципліну «Прогностична діяльність в галузі інформаційних технологій» (довідка про впровадження № 300/1 від 14.05.2021р.). В. Бабкіним розроблено й упроваджено з формування інформаційноаналітичної компетентності майбутніх бакалаврів комп’ютерних наук навчальну дисципліну за вибором «Інформаційно-аналітичні системи та технології» (довідка про впровадження № 300/2 від 14.05.2021р.). Результати досліджень аспірантів знаходили своє відображення в одноосібних та/або спільних 3 керівником дослідження публікаціях (статтях, тезах доповідей тощо).

Крім зазначеного, здобувачі ОНП вільно брали участь у заходах 3 освітньої, наукової, науково-дослідної діяльності, що проводяться як в Україні так і за їі межами, залучались до наукових досліджень на засадах академічної свободи. Під час освітнього процесу за ОНП аспіранти проводили наукові дослідження в рамках виконання НДР кафедри «Модернізація професійно-педагогічної освіти в Україні в умовах інтеграції до світового освітнього простору» (№ 0112U002287, 2012-2017рp.) і «Теоретичні та методичні засади моделювання компетентнісної професійної освіти у контексті євроінтеграції» (№ 0717U004331, 2017-2022рр.).

Результати спільних наукових досліджень здобувачів та їх наукових керівників публікувалися у фахових виданнях Університету (Вісник Університету імені Альфреда Нобеля. Серія «Педагогіка і психологія». Педагогічні науки, видається 32010 р.), збірниках наукових праць, зокрема, за результатами щорічних науково-практичних конференцій для студентів, аспірантів і науковців: міжнародних: «Практична психологія у сучасному вимірі», «Сучасна вища освіта: перспективні та пріоритетні напрями наукових досліджень»; всеукраїнській: «Сучасна вища освіта: проблеми та перспективи».

Зупинимося на діяльності Клубу аспірантів, метою якого $\epsilon$ створення сприятливих умов для формування у членів клубу активної соціальної позиції, професійної та особистісної культури, креативності, нестандартності мислення, «гнучких» (softskills) навичок, виховання громадянської самосвідомості, спрямування їх інтелектуальних, наукових, професійних та інших можливостей для 
творчого зростання, підвищення професійного рівня 3 метою якісного супроводження освітнього процесу, розширення сфери науково-дослідної та інноваційної діяльності, збереження та примноження традицій і духовних цінностей Університету.

Майбутні доктори філософії беруть участь в організації і проведенні тематичних клубних засідань, семінарів, диспутів, круглих столів, майстер-класів, тренінгів, спрямованих на формування у здобувачів вищої освіти ступеня доктора філософії комплексу неспеціалізованих надпрофесійних «гнучких компетентностей» (soft skills), а також організації різних розвивальних заходів (спектаклі, творчі вечори), відвідування театрів, органної зали, виставок тощо.

Цікавими для аспірантів виявились засідання Клубу аспірантів, які дали можливість їм бути в курсі актуальних наукових подій; вчасно отримувати інформацію про стажування, наукові конкурси і гранти; обмінюватися досвідом 3 одногрупниками, викладачами, науковими керівниками, випускниками; дізнаватися про можливості кар'єрного росту, існуючі дослідницькі інструменти та перспективи практичного застосування потенціалу на ринку праці.

Зупинимося на соиіально-психологічному супроводі майбутніх докторів філософії під час написання та реалізаџіï дисертаційного проєкту. Наукова діяльність аспірантів нерозривно пов'язана 3 впливом на них несприятливих екологічних, соціальних, педагогічних, професійних, сімейних та інших факторів, що «супроводжується виникненням, розвитком негативних емоцій, сильних переживань, а також перенапруженням фізичних і психічних функцій» ${ }^{58}$. Соціальна роль «майбутнього доктора філософії» пов'язана із задоволенням інтелектуальних потреб. Поставивши понад усе інтелектуальні навантаження, аспіранти піддають організм нескінченним психічним перевантаженням, тому їм потрібно вміти не тільки заповнювати свої ресурси, а й мудро витрачати їх. Для цього повинна бути сформована здатність керувати власними психічними станами і поведінкою, з тим, щоб оптимальним чином діяти в складних ситуаціях ${ }^{59}$. Ці факти переконують у необхідності

${ }^{58}$ Бильданова В., Бисерова Г., Шагивалеева Г. Психология стресса и методы его профилактики: учеб.-метод. пособ. Елабуга : Издательство ЕИ КФУ, 2015. 142 с.

${ }^{59}$ Бильданова В., Бисерова Г., Шагивалеева Г. Психология стресса и методы его профилактики: учеб.-метод. пособ. Елабуга : Издательство ЕИ КФУ, 2015. 142 с. 
надання сочіально-психологічної допомоги майбутнім докторам філософії при написанні та реалізації дисертащійного проєкту.

3 иією метою у ВНЗ «Університет імені Альфреда Нобеля» створено соціально-психологічну службу для надання психологічної та соціально-педагогічної допомоги, забезпечення психологічної підтримки та супроводу здобувачів вищої освіти. Основною метою діяльності соціально-психологічної служби є психологічне забезпечення та підвищення ефективності освітнього процесу, захист психологічного здоров'я і соціального благополуччя аспірантів та науково-педагогічного колективу. Члени соціально-психологічної служби надають індивідуальні та групові психологічні консультації учасникам освітнього процесу в аспірантурі, організовують психологічну діагностику за запитом, проводять лекції, семінари просвітницького характеру, соціально-психологічні тренінги, забезпечують підвищення рівня психологічної культури, стресостійкості аспірантів під час написання та реалізації дисертаційного проєкту, а також у міжособистісному спілкуванні.

Так, членами сочіально-психологічної служби та запрошеними фахівиями були організовані такі практичні майстер-класи: «Арт-терапія в роботі з питаннями самооцінки, самоцінності та впевненості в собі», «Збереження емоційної рівноваги під час карантинних обмежень Covid-19», «Як приручити свої страхи», «Лайфхаки сучасного тайм-менеджменту», майстер-клас 3 психологічної травми тощо.

Отже, освітньо-наукова програма «Професійна освіта» на третьому (освітньо-науковому) рівні вищої освіти, яку було розроблено та реалізується у ВНЗ «Університет імені Альфреда Нобеля», передбачає можливості для підготовки майбутніх докторів філософії до написання та реалізації дисертаційним проєктом.

Для підтвердження цієї точки зору нами у травні 2021 року було проведено опитування 27 аспірантів. Опитування проводилось шляхом онлайн-анкетування респондентів за допомогою сервісів Google.

В таблиці 5 і рисунку 4 наведені дані рівня наявних можливостей для підготовки до написання та реалізації дисертаційного проєкту на думку аспірантів. 
Таблиця 5

Розподіл відповідей на питання «Оцініть, в якій мірі Ви можете
формувати готовність до написання та реалізації
дисертаційного проєкту в ВНЗ «Університет імені Альфреда

Нобеля» за окремими характеристиками?», \%

\begin{tabular}{|c|c|c|c|c|}
\hline \multirow[b]{2}{*}{ № } & \multirow[b]{2}{*}{ Характеристики } & \multicolumn{3}{|c|}{ Думка аспірантів } \\
\hline & & 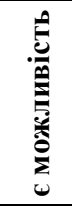 & 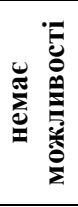 & 蒠 \\
\hline 1. & $\begin{array}{c}\text { Наявність навчальних дисциплін, які } \\
\text { розкривають особливості проєктної діяльності в } \\
\text { педагогічній та дослідницько-інноваційній } \\
\text { діяльності }\end{array}$ & 92,6 & 0 & 7,4 \\
\hline 2. & $\begin{array}{l}\text { Відкрите проєктно-орієнтоване освітнє } \\
\text { середовище університету і кафедри }\end{array}$ & 88,9 & 0 & 11,1 \\
\hline 3. & $\begin{array}{c}\text { Можливість участі в міжнародних програмах } \\
\text { та проєктах }\end{array}$ & 100 & 0 & 0 \\
\hline 4. & $\begin{array}{c}\text { Викладачі транслюють особисту зацікавленість } \\
\text { та прагнення до цілеспрямованої, послідовної та } \\
\text { продуктивної проєктної діяльності } \\
\end{array}$ & 88,9 & 0 & 11,1 \\
\hline 5. & $\begin{array}{c}\text { Створені умови для набуття практичних умінь і } \\
\text { навичок щодо практичного використання } \\
\text { відповідного інструментарію з питань } \\
\text { виконання робіт дисертаційного проєкту } \\
\end{array}$ & 92,6 & 3,7 & 3,7 \\
\hline 6. & $\begin{array}{c}\text { Отримання консультативної, організаційної, } \\
\text { соціально-психологічної допомоги під час } \\
\text { написання та реалізації дисертаційного проєкту }\end{array}$ & 96,3 & 0 & 3,7 \\
\hline 7. & Кар'єрний ріст & 85,2 & 7,4 & 7,4 \\
\hline 8. & $\begin{array}{c}\text { Створені умови для проведення досліджень та } \\
\text { підвищення кваліфікації } \\
\end{array}$ & 96,3 & 0 & 3,7 \\
\hline & Середнє значення & 92,6 & 1,4 & 6,0 \\
\hline
\end{tabular}




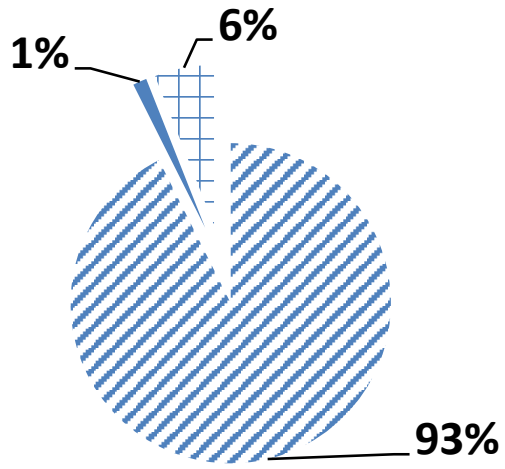

Рис. 4. Середнс значення відповідей аспірантів щодо наявних можливостей для підготовки до написання та реалізації дисертаційного проскту в ВНЗ «Університет імені Альфреда Нобеля»

Можна з упевненістю сказати, що зміст, форми та методи підготовки докторів філософії до написання i реалізації дисертаційного проєкту у ВНЗ «Університет імені Альфреда Нобеля» підібрано правильно і це підтверджує більшість аспірантів кафедри інноваційних технологій 3 педагогіки, психології та соціальної роботи $(92,6 \%)$. А це означає, що Університет обрав правильний шлях вирішення поставлених завдань щодо формування у аспірантів необхідних компетентностей, які допоможуть написати і реалізувати дисертаційний проєкт, а саме: здійснювати критичний аналіз, узагальнювати результати наукових досліджень; демонструвати комплексні знання релевантної наукової літератури 3 проблем дослідження та усвідомлювати професійну значущість цих знань; проєктувати та реалізовувати індивідуальну освітню траєкторію, застосовувати принципи наукової самоорганізації, власного дослідницького стилю; доводити результати досліджень та інновацій та публічно їх представляти, обговорювати і дискутувати 3 науково-професійною спільнотою; демонструвати лідерські якості, навички міжособистісної взаємодії, вміння працювати в команді дослідників, дотримуючись принципів наукової етики, планувати, 
організовувати та проводити оригінальні наукові дослідження у сфері професійної освіти, тощо.

Висновки. Проведене дослідження дало можливість сформулювати такі висновки:

1. Доведено, щуо поняття «дисертаџійний проєкт» передбачає проведення конкретного наукового дослідження. Тому під час підготовки майбутніх докторів філософії доцільно використовувати саме термін «дисертаційний проєкт».

2. Уточнено поняття «підготовка до написання i реалізації дисертаційного проєкту», яке визначається як система змістовнопедагогічних та організаційно-методичних заходів, реалізація яких забезпечує формування готовності майбутнього доктора філософії до написання і реалізації дисертаційного проєкту.

3. Здійснене пілотне дослідження дало можливість підтвердити тезу про те, щзо підготовка до написання та реалізації дисертаційного проєкту $\epsilon$ важливою складовою професійної діяльності доктора філософії.

4. Визначено фактори, від яких залежить ефективність написання та реалізації дисертаційного проєкту: підтримка наукового керівника, колег, сім'ї тощо; атмосфера інтенсивного обміну інформацією і відкритої комунікації; ефективна взаємодія зі стейкхолдерами дисертаційного проєкту; створення банку ідей i результатів дисертаційного проєкту, який повинен включати ідеальний, реальний продукт, що володіє об 'єктивною новизною.

5. Розкрито такі особливості підготовки до написання та реалізації дисертаційного проєкту майбутніх докторів філософії, які навчаються за освітньо-науковою програмою «Професійна освіта» (спеціальність 015 Професійна освіта (за спеціалізаціями)) у ВНЗ «Університет імені Альфреда Нобеля»: 1) включення до обов'язкових професійних компонентів освітньо-наукової програми навчальний курс «Управління проєктами в сфері освіти», а до переліку вибіркових професійних компонентів - навчальну дисципліну «Фандрайзинг в освітній діяльності»; 2) попереднє ознайомлення викладачів із темами дисертаційних досліджень аспірантів 3 метою більш цілеспрямованого моделювання змісту освітнього компоненту; 3) проєктування змісту кожного заняття 3 акцентами на тих питаннях, які $\epsilon$ вагомими для написання дисертаційного проєкту; 4) організація пошукової дослідницької діяльності аспірантів засобами інформаційних технологій; 5) відображення наукових досягнень аспірантів в освітньому процесі 
ВНЗ «Університет імені Альфреда Нобеля»; 6) вільна участь здобувачів вищої освіти у заходах з освітньої, наукової, науководослідної діяльності, що проводяться як в Україні так і за ії межами, залучення їх до наукових досліджень на засадах академічної свободи; 7) публікація результатів спільних наукових досліджень здобувачів та їх наукових керівників у фаховому виданні Університету, збірниках наукових праць, зокрема за результатами щорічних науково-практичних конференцій для студентів, аспірантів i науковців; 8) участь у засіданнях Клубу аспірантів; 9) надання соціально-психологічного супроводу майбутнім докторам філософії під час написання та реалізації дисертаційного проєкту.

У межах отриманих результатів можна намітити перспективу подальшого студіювання прочесу підготовки майбутніх докторів філософії до написання та реалізації дисертаційного проєкту відповідно до етапів роботи над проєктом. 